\title{
Wake Up Call Messages: Shadowing Technique with Listening Logs to Improve Students Oral Performance
}

\author{
Agrissto Bintang Aji Pradana ${ }^{1}$, Sukma Wijayanto ${ }^{2}$, Umi Nasehatul Fadilah ${ }^{3}$ \\ \{agrisstobintang@ummgl.ac.id ${ }^{1}$ \}
}

Elementary School Teacher Education Department, Universitas Muhammadiyah Magelang, 56125, Indonesia ${ }^{1,2,3}$

\begin{abstract}
The ability in oral communication is one of the goals in ELT in university levels. However, lack of models and practices become considerable factors of why students sometimes find it so difficult. This study attempts to improve students' oral performance in terms of fluency, pronunciation, and accuracy. It employed a Classroom Action Research conducted through two cycles. 20 first-year students of Elementary School Teacher Education of UNIMMA, Indonesia were assigned as participants. A shadowing technique supported by daily listening logs was carried out within 6-week practices. Oral test was taken to assess their oral performance. As attempt to find out their improvement in details, journals in form of daily recordings were investigated as well. Then data were analyzed using descriptive qualitative approach. Findings show there was an increase of mean scores from pre-cycle (62.7), cycle I (68.9), to cycle II (73.25). The activity logs contributed to this improvement as well. It was highlighted from the average scores of their daily activity logs. Hence, shadowing technique enhanced oral performance when assisted with listening logs. The results could be adapted by educators or parents when they attempt to improve their students speaking skills using shadowing technique.
\end{abstract}

Keywords: action research; listening logs; oral performance; shadowing

\section{Introduction}

Speaking plays crucial roles in academic settings. It gives lots of contribution and becomes considerable factor for successful communication [1]. When speaking students are constructing and sharing meaning in verbal symbols. Here they also convey messages, ideas, and thoughts. Also, job markets really demand graduates with outstanding proficiency in English, especially in speaking [2]. Though it becomes a fundamental aspect in business and educational settings, it is considered difficult and challenging in language learning [3].

Speaking has its own components which give significant contribution, e.g. vocabulary, grammar, fluency, pronunciation, and comprehension [4]. Fluency itself can be considered as an oral proficiency which variables are appropriateness, lexical range, and correctness [5]. Other factors also influence learners' proficiency e.g. family support, exposure to language, attitudes, and teaching strategies [6].

In fact, students' language skills in terms of listening and speaking skills are still low. Listening is considered as language skill which also contributes to the success of oral performance. It is a receptive skill which deals with memory strategy, comprehension, pronunciation, and intonation patterns. 
Though listening is becoming one of significant contributors, it is still considered difficult indicated by achievement of those components [7]. In reality language learners find difficulties to express ideas in spoken language [3]. This occurs on linguistics knowledge (such as phonemes, words, grammatical structures, pronunciation, and accent) and non-linguistics knowledge (such as topic and main idea, general knowledge about the world) makes listening difficult for the students [8].

Shadowing is one of techniques which facilitates learners to speak in the classroom. It assumes that learners improve their oral performances through listening and repeating practices [9]. It also emphasizes on paced supported by auditory tracking task [10]. It is a technique commonly known to improve interpreting skills [11].

Dealing with applying shadowing technique in promoting oral practices, a number of studies conducted this technique to improve self-confidence and speaking ability [12][13], fluency [14]-[16], [3] [5], pronunciation [17]-[19]. However, the prior studies have not revealed the practical discussions of the treatment yet. Besides they do not explore the practices in university contexts. The present study is aimed at investigating the role of Shadowing technique in improving students' oral performance. Moreover, it discusses a practical experience using Shadowing technique in university levels. It gives much contribution to teaching and learning English as foreign language practices.

\section{Method}

A Classroom Action Research was employed in this study. 20 first semester students of Elementary School Teacher Education Department of Universitas Muhammadiyah Magelang were assigned as the subjects. They practiced listening and speaking skills using Shadowing technique throughout sis-week treatment. The audio used in the treatment presented a number of sentences and conversations taken from Interchange [20]. The shadowing phases carried out during the treatment were adapted from Kadota and Tamai cited in [21]. The treatment was conducted within 2 cycles and took 3 weeks for each cycle. During the treatment students were provided with a number of messages (listening logs) sent early morning via WhatsApp attached with audio of expressions and dialogues, materials, and the discussions. It focused on how students listened to utterances or conversations, read the script, imitated, simulated the sound as well as the speakers utter then learned the contents. Then they recorded their voices and upload to Univ LMS. The phases done by the students were presented as follows:

1. Mumbling: Students listen to the incoming sounds and focus on what the speakers pronounce/say

2. Prosody shadowing: Students shadowed the utterances as they did in the previous phase without reading any script.

3. Content shadowing: Students shadowed the speech then paid much attention to the contents of the speech.

Data were gathered through tests supported by documentary-method. Tests were taken to obtain data regarding students' oral performance. They were given a set of situation and then did role play related to it. Their performance got observed during the tests. While their personal development (pronunciation, intonation, and fluency) was observed from their weekly recordings (journals) uploaded to our LMS as their personal portfolio. It employed qualitative approach to analyze the data. 
To assess students' oral performance, some criteria could be taken as the rubric's guideline, e.g. cohesion, vocabulary, syntax, pronunciation, and fluency [22] but this study only assigned the speaking micro skills (pronunciation, intonation, and fluency) as the scoring criteria.

\section{Results and Discussion}

\subsection{Result}

The preliminary study revealed that there was a problem regarding students' oral performance. This study was attempted to ease the difficulties and overcome the problem. To ensure that the problem really existed, a pre-cycle test was conducted. It showed the average score of students' oral performance was 62.7 in terms of pronunciation, intonation, and fluency. It was considered low and needed to be enhanced through the teaching and learning quality development. It was difficult for them since they learned English as their foreign language. They could not express their ideas as fluent and confident as with their mother tongue. Besides they lack of practice even though they had lots of references and online media to learn English. Also, most of them lack of knowledge of target language so they still needed a guide during selflearning.

To overcome the problems, the treatment called Wake up call messages was provided in Cycle I. It was sent to the students guiding them to practice their listening and speaking. They were regularly drilled with a number of long conversations provided by some notes as the materials and exercises. Different messages were sent within 3-5 days a week. The materials also became a part of the topics later discussed in the classroom.

When they practiced speaking in the class, they seemed to understand quite well how to pronounce the sentences correctly. After 3 meetings, they took the exam and the results showed an increase in oral performance in terms of pronunciation, intonation, and fluency. However, referring to activities in class, more than half of the students had difficulty pronouncing long sentences. The recordings taken from the LMS said so. Oral test conducted at the end of Cycle I showed an increase of students' oral performance.

Reflection was conducted to evaluate the learning process carried out in Cycle I. Suggestions were strongly addressed that the dialogs given to the students were considered too long. Besides, since English was considered as their foreign language, it was rather difficult for them to pronounce the sentences accurately. It had better attach the transcript along with the dialogues. As a result, in Cycle II the dialogues were presented little shortened and accompanied by written explanation dealing with how to pronounce them.

In Cycle II a Synchronized reading was added in the shadowing phases. Students shadowed the audio, read the transcript, simulated every sentence they heard focusing on intonation, stress, and pace [21]. Students practiced listening and oral skills assisted by Wake-up call messages throughout the cycles. Their pronunciation, intonation, and fluency improved with practices in week by week as presented in Table 1 . 
Table 1. Students' portfolio scores of oral performances

\begin{tabular}{ccccccc}
\hline $\begin{array}{c}\text { Listening } \\
\text { Logs }\end{array}$ & $\begin{array}{c}\text { Wake up } \\
\text { call } \\
\text { message 1 }\end{array}$ & $\begin{array}{c}\text { Wake up } \\
\text { call } \\
\text { message 2 }\end{array}$ & $\begin{array}{c}\text { Wake up } \\
\text { call } \\
\text { message 3 }\end{array}$ & $\begin{array}{c}\text { Wake up } \\
\text { call } \\
\text { message 4 }\end{array}$ & $\begin{array}{c}\text { Wake up } \\
\text { call } \\
\text { message 5 }\end{array}$ & $\begin{array}{c}\text { Wake up } \\
\text { call } \\
\text { message 6 }\end{array}$ \\
\hline Pronunciation & 6.35 & 6.80 & 7.25 & 7.50 & 7.6 & 7.75 \\
Intonation & 6.05 & 6.75 & 7.15 & 7.15 & 7.35 & 7.45 \\
Fluency & 5.85 & 6.40 & 6.65 & 6.85 & 7.05 & 7.15 \\
\hline
\end{tabular}

After six-week treatment, an oral test was taken and showed an increase of students' oral performance 73.25. The performance was improving in each cycle as presented in Table 2.

Table 2. Scores of oral performance tests

\begin{tabular}{cccc}
\hline N & Pre-cycle & Cycle 1 Test & Cycle 2 Test \\
\hline 20 & 62.7 & 68.9 & 73.25 \\
\hline
\end{tabular}

Although, good figures and tables are interesting and easy to understand, but the most important thing is that the results / data presented in the figure or table are honest. If an image can only be understood with the support of research data which may require half or a full page of paper, then the data should be included as an appendix. Do not hide important data that raises reader questions or leads to mistrust of the reader.

The results section is written following the chronological order as presented in the method section. The important thing in presenting results is that the author must not include references in this section. This section is the "findings" of the author himself. However, if the results of the study are presented in a figure or table that directly compares with the findings of another person, the part of the figure or table must include the findings of that other person, without the need to discuss it in this section.

\subsection{Discussion}

Results reveal that the application of shadowing technique has an impact on improving students' oral performance. Learning speaking cannot merely be separated from listening activities. Thus, listening practices also give contribution to increase oral skills. This technique is considered to improve listening skills [21] and listening comprehension skills [23][24].

Shadowing technique consists of phases (mumbling, prosody shadowing, synchronized reading, and ending with content shadowing). The early phase emphasizes listening and imitating practices then confirming what students just heard with the correct transcript. Shadowing technique facilitates students to imitate and repeat [3] as in working memory auditory input will be erased sooner when it is not rehearsed [16].

Then students read and listen, then reproduce the text (repeat, select, summarize orally) [3]. In this activity students do not only listen and imitate, but also select the oral information. Thus, they understand the content and meaning of the sentence, question, or dialogue they are listening to. At the end students are able to pronounce the input language. This is caused by an input to the working memory. Memory will recall verbal input and it led to good oral production [16]. The results show a relationship between shadowing technique and fluency of learners' oral performance in EFL context [14]. However, the results do not support the study [5] who stated that shadowing technique does not promote students' fluency. 


\section{Conclusion}

The present study attempts to increase students' oral performance using Shadowing technique. It was carried out in some phases including mumbling, prosody shadowing, synchronized reading, and ending with content shadowing. Listening logs provided to the students successfully assisted their listening and oral practices throughout two cycles. Hence it improved their pronunciation, intonation, and fluency. It gives much contribution to development of oral skills teaching and learning practices and is considered as relevant references for other studies. However, it only explores the implementation of Shadowing technique in terms of pronunciation, intonation, and fluency in university levels. Different components of oral performance are strongly suggested to explore for future studies.

\section{Acknowledgement}

The author expresses his thanks to Universitas Muhammadiyah Magelang for the financial supports in publishing this work, reviewers, and proof-readers.

\section{References}

[1] T. Oradee, "Developing Speaking Skills Using Three Communicative Activities ( Discussion , Problem-Solving, and Role- Playing ),” Int. J. Soc. Sci. Humanit., vol. 2, no. 6, pp. 533-535, 2012.

[2] S. Farooqui, "Developing speaking skills of adult learners in private universities in Bangladesh: problems and solutions," Aust. J. Adult Learn., vol. 47, no. 1, pp. 95-110, 2007.

[3] F. Yavari, S. Shafiee, and S. Branch, "Effects of Shadowing and Tracking on Intermediate EFL Learners ' Oral Fluency,” Int. J. Instr., vol. 12, no. 1, pp. 869-884, 2019.

[4] L. Leong and S. M. Ahmadi, "An Analysis of Factors Influencing Learners 'English Speaking Skill," Int. J. Res. ENglish Educ., vol. 2, no. 1, pp. 34-41, 2017.

[5] Y. Muraoka, "Shadowing and Fluency: How does Shadowing Practice Promote Fluency in the EFL classroom ?," Keisen Univ. Bull., vol. 29, pp. 93-112, 2017.

[6] T. Triwittayayon, "Factors Enhancing English Speaking Ability: Perspectives from Thai High School Students and Their Teachers," Thai TESOL J., vol. 31, no. 1, pp. 49-64, 2018.

[7] J. Y. Chao, "Factors Affecting College EFL Learners ' Listening Comprehension and Listening Problems," NCUE J. Humanit., vol. 8, pp. 71-84, 2013.

[8] M. A. Bingol, B. Celik, N. Yildiz, and C. T. Mart, "Listening Comprehension Difficulties Encountered by Students in Second Language Learning Class,” J. Educ. Instr. Stud. World, vol. 4, no. 4, pp. 1-6, 2014.

[9] M. Bashir and M. Azeem, "Factor Effecting Students 'English Speaking Skills," Br. J. Arts Soc. Sci., vol. 2, no. 1, pp. 34-50, 2011.

[10] S. Lambert, "Shadowing," Meta J. des traducteurs Transl. J., vol. 37, no. 2, pp. 263-273, 1992.

[11] K. Shiota, "The Effectiveness of Shadowing on Students ' Psychology in Language Learning," Asia, vol. 5, no. 1, pp. 71-83, 2012.

[12] Y. Kuo, "Effect of Text Shdowing on Taiwanese EFL Children's Pronunciation," Asian EFL J., vol. 16, no. 2,2014

[13] J. F. Nashta and R. Rahimy, "An Ivestigationof the Effectiveness of Dialogue Shadowing Technique (DST) on Iranian Intermediate EFL Learners' Conversation," Int. J. Res. English Educ., vol. 3, no. 2, pp. 34-47, 2018. 
[14] E. Zakeri, “The Effect of Shadowing on FL Learners' Oral Performance in terms of Fluency,” Int. J. English Lang. Teach., vol. 2, no. 1, pp. 21-26, 2014.

[15] X. Wang, "The Study of Shadowing Exercise on Improving Oral English Ability for Non-English Major College Students," in World Conference on Management Science and Human Social Development, 2018, vol. 120, pp. 195-200.

[16] J. Wiltshier, "Fluency through Shadowing-What, why, and how?," in JALT Conference Proceedings, 2007, pp. 498-506.

[17] J. A. Foote and K. Mcdonough, "Using Shadowing with Mobile Technology to Improve L2 Pronunciation,” J. Second Lang. Pronunciation, vol. 1, no. 2014, pp. 34-56, 2017.

[18] M. Dávila and E. V. E. J, "Using the Shadowing Technique to Improve Ecuadorian ENglish Learners' Speaking Intelliginility,” Int. J. Curr. Res., vol. 10, no. 12, pp. 76770-76772, 2018.

[19] H. Omar, "Using 'A Shadowing', Technique ' to Improve English Pronunciation Deficient Adult Japanese Learners : An Action Research on Expatriate Japanese Adult Learners," JOUR AL ASIA TEFL, vol. 7, no. 2, pp. 199-230, 2010.

[20] J. C. Richards, J. Hull, and S. Proctor, Interchange, 4th ed. New York: Cambridge University Press, 2013.

[21] Y. Hamada, “An Effective Way to Improve Listening Skills through Shadowing," Lang. Teach., vol. 36, no. 1, pp. 3-10, 2012.

[22] D. Srikaew, K. Tangdhanakanond, and S. Kanjanawasee, "Development of an English Speaking Skill Assessment Model for Grade 6 Students by Using Portfolio," Procedia - Soc. Behav. Sci., vol. 191, pp. 764-768, 2015.

[23] Y. Hamada, "Improvement of Listening Comprehension Skills through Shadowing with Difficult Materials,” J. ASIA TEFL, vol. 8, no. 1, pp. 139-162, 2011.

[24] Y. Hamada, "The Effectiveness of Pre- and Post-Shadowing in Improving Listening Comprehension skills," Lang. Teach., vol. 38, no. 1, pp. 3-11, 2014. 